\title{
Paradigmatic Changes, or are Local Self-Governments Before or After Changes in Hungary?
}

\author{
Transformation of the Regulation \\ of Local Self-Governments
}

\begin{abstract}
KLÁra GuRdON-NaGY*
Abstract. Scientific discussions concerning local governments are pervaded by paradigms at all times, which are questioned from time to time (paradigm crisis). As a result, participants of these discussions either defend their points, or a new paradigm appears (change in paradigm). I examine the system of local governments from this aspect. What kind of and how many paradigms characterise the system of local governments? Are these explainable by the paradigm? If not, is there another explanation? In this study, I gather all the current and emerging (perhaps former) characteristics of the local government system. In that regard, I determined the principles that, in my opinion, either apply at the level of the local government system, or they are in crisis.
\end{abstract}

Keywords: paradigms, local governments in Hungary, changes in Hungarian municipal system

\section{INTRODUCTION}

Thomas Kuhn defined paradigms in his book The Structure of Scientific Revolutions (1962) as generally accepted, closed disciplines of a field of science which exist in a certain era and - in my opinion - in a certain geographical area. Consequently, scientific truth is not an objective category, but it is always an institutionalised consensus of a scientific community existing in a certain era and place. ${ }^{1}$

In this study, I examine the paradigms of local self-government and their changes in Hungary. In which period are self-governmental rights and the local self-governmental system in Hungary today? What kind of and how many anomalies characterise the governmental system? Are these anomalies unexplainable by paradigms? Do unexplainable anomalies call the paradigms of local self-governments into question? Is there another explanation system? In the present study, I try to collect the current and emerging (perhaps former) characteristics of the local government system at the level of constitutional law (which is based on the Fundamental Law and on the case-law of the Constitutional Court) and of administrative law (the respective cardinal act and other specific laws). Related thereto, I determine the principles that, in my opinion, underlie the local government system or live their crisis.

* Széchenyi István University, Győr, nagy.klara01@gmail.com.

1 Varga (2004) 182. 


\section{HAVE EXPECTATIONS CHANGED? OR ARE THEY JUST BEFORE A POSSIBLE PARADIGM CHANGE?}

\subsection{The Constitutional Status of Local Self-Governments in Hungary}

State power and local self-government power are based on different legitimacies, but do not exist separately, they are part of a single public authority. ${ }^{2}$ Public authority of the local selfgovernment is characterised by some autonomy, which separates the local community from state power, but they cooperate closely with each other. ${ }^{3}$

In Hungary, the Fundamental Law states only that 'local governments shall function to manage local public affairs and exercise local public power'. [Art. 31(1) of the Fundamental Law $]^{4}$ The Fundamental Law determines local self-governments as seen from their activities (managing local public affairs and exercising local public power) and does not mention right to local self-governance. ${ }^{5}$ Thus, the existence of local self-governments is considered to be an administrative organizational principle. They are a part of state organization, such as, for example, the Parliament, the Government or the courts, and it is beyond dispute that the foundation of deconcentrated organs and the shape of their competence always affect local self-governments. ${ }^{6}$

With regard to classic branches of power, local self-governments shall be considered as part of the executive branch, but shall be separated from central state organs, namely from the Government, being at the top of the executive branch and the ministries. [Art. 15(2) of the Fundamental Law] Consequently, the executive branch can be identified with public administration, which has two parts: the state administration and the municipal administration. The latter term refers to the vertical allocation of the executive branch. [Decision 55/1994. (XI. 10.) AB, ABH 1994, 296, 302.] ${ }^{7}$ In the case-law of the Constitutional Court, the difference between the Government and local self-governments is municipal autonomy. ${ }^{8}$

The Constitution guarantees that local self-governments are not subordinate to the Government, only the Parliament is entitled to adopt compulsory rules for them.

2 Preamble of Act 2011 of CLXXXIX on Local Governments in Hungary (hereinafter referred to as 'Local Governments Act').

${ }^{3}$ Küpper (2009) 1503.

${ }_{4}$ The rule of the European Charter of Local Self-Government (hereinafter referred to as 'Charter') is also similar to this definition: 'Local self-government denotes the right and the ability of local authorities, within the limits of the law, to regulate and manage a substantial share of public affairs under their own responsibility and in the interests of the local population.' [1 point of Art. 3 of the Charter] This also shows that regulation and management of local public affairs is the selfgovernance. However, its content is defined neither by the Charter.

5 The Fundamental Law reflects a different approach from the Constitution: the Constitution still declared the right to self-governance and the fundamental rights of local communities. [Art. 4243 of the Constitution] The right to local self-governance can be perceived as the right of local community, however, local self-governance is practiced by the voters through the body of representatives. It causes some contradiction, as they have no continuous call-back right and right to instruction. The certain affairs to be managed are not addressed to local communities, but to local governments. Therefore, it would be more correct to speak about the principle of local governance, just like it is in the Charter. [Verebélyi (1995a) 489.]

${ }^{6}$ Ivancsics (1994) 171.

7 Pálné (1997) 115.

8 Küpper (2009) 1504. 
The existence of municipalities depends on the decision of the Parliament (e.g. it dissolves the representative bodies, if their operation is in conflict with the Fundamental Law), which also decides about the formation and the framework of their operation, their organization ensuring greater autonomy than state administrative organs. [Art. 1(2)g) of the Fundamental Law]

Within the framework of decentralization, the State (the Parliament) allocates the tasks to administrative organs, which provides them with great autonomy; namely, local selfgovernments perform decentralized state tasks. A further feature of decentralization is that tasks are performed at the local level. [Art. 31(1) of the Fundamental Law] ${ }^{9}$ Decentralization is ensured by Acts of Parliament. Compulsory tasks can be conferred to the local governments only by Acts, while local governments may perform chosen tasks and voluntarily assumed tasks ${ }^{10}$ beyond compulsory ones [Art. 10(1) of the Local Governments Act]. The Parliament shall ensure the financial sources as the 'compensation' of the tasks and shall determine the financing system.

Imre Ivancsics is of the view that more tasks go along with more restrictions, namely if local governments get more tasks, the state influence increases, because compulsory tasks entail state control. ${ }^{11}$ I do not agree with that, as it is obvious that performing a task cannot happen without control; but if there is no task in which the local government may decide autonomously, it can lead to depriving local self-governments of their substance.

The definition of the right to local self-governance was transferred to the Local Governments Act: ${ }^{12}$ 'Eligible voters of the settlements (municipalities in settlements) and the counties (regional municipalities) have the right to local government.' [Art. 3(1) of the Local Governments Act] According to the Constitutional Court, there has not been a significant change compared to the rules in the Constitution by interpreting together the provisions of the Fundamental Law and the Local Governments Act, as the criterion of constitutionalism regarding the right of self-governments is the following: if the practice of the rights and obligations of local governments is ruled in the way that it leads to depriving them of the fundamental rights laid down in the Constitution [now: Local Governments Act - the Author], then it excludes that the local government may decide with autonomous responsibility within its terms of competence. [Decision 1/1993. (I. 13.) AB, ABH 1993,

9 Szente (1994) 369.

10 The group of voluntarily assumed (alternative) tasks is considered as a transition between the compulsory and the chosen tasks, while, according to another view, the chosen task divides into two groups: the facultative and the alternative tasks. Under the Local Governments Act, 'another selfgovernment in settlements or their association may take over the compulsory tasks provided for local governments in settlements with greater economic performance and with a larger population with their consent, if it is able to perform the tasks

a) upon justified residential demand;

b) in a more efficient way and at least at the same level of expertise;

c) without extra state aid.' [Art. 12(1) of the Local Governments Act] The voluntarily assumed tasks are of transitional nature: it is voluntarily with regard to that the local self-government is free to decide whether to perform the task, but in the absence of such undertaking it is compulsory with regard to that the bigger local government shall perform it under the Act. [Hoffman (2013) 11.]

11 Ivancsics (1994) 172.

12 Murányi (2015) 11. 
27.] Béla Pokol takes the opposing view. He set out in his dissenting opinion of the decision that there has been a conceptual change: the declaration of the right to self-governance as a fundamental right was transferred from the Constitution to the Local Governments Act, and so the right to self-governance is no longer a fundamental right, only a rule of competence, an administrative organizational principle. (Decision 18/2013. (VII. 3.) AB, Minority Report [20]\} In my opinion, it would have been more appropriate to regulate the principle of local self-governance, so it could take the sting out of the disputed situation.

It is a fact that the existence of local governments constitutes an issue of state structure and not of fundamental rights. ${ }^{13}$ This standpoint is present also in the European Charter of Local Self-Government. The Charter prescribes that 'the principle of local self-government shall be recognised in domestic legislation, and where practicable in the constitution'. [Art. 2 of the Charter] However, the Charter thereby requires only that the states shall rule local self-governments as a principle, and it is not necessary to handle them as a collective fundamental right; neither does it state that local governments shall be determined in a constitution.

Moreover, the levels of the local self-governments are determined in the Local Governments Act: the voters of settlements and counties have the right to local government. [Art. 2(1) and 3(1) of the Local Governments Act] Earlier, the Constitution regulated the levels of local governments, which were the following: communities, cities, the capital and its districts, and counties. [Art. 42 of the Constitution] It must also be added that beyond these levels, cities with county rights and regions, sub-regions also existed. ${ }^{14}$ The Fundamental Law does not rule anything about territorial entities. However, under the Local Governments Act the voters of all settlements continued to have the right to selfgovernments. As a matter of fact, the administrative spatial structure has not changed in the past 30 years in this regard. ${ }^{15}$

However, it should be pointed out in this regard that the Monitoring Committee of the Council of Europe expressed dissatisfaction at its monitoring visit of 2012 with the fundamental rights not being determined in the Fundamental Law, and the rules set out in a cardinal Act not providing sufficient guarantees. ${ }^{16}$ The Fundamental Law guarantees only the existence of local governments, and not their competences, their numbers, their

13 Ujlaki (2018) 99.

14 The Fundamental Law no longer determines the levels of local governments; therefore, it is not a constitutional fundamental right that every settlement have local governments. Thus their constitutional protection had ceased, and so it would not be contrary to the Fundamental Law, if the Parliament did not ensure the opportunity of formation of local governments for all settlements. It does not violate the Charter, as it only states that 'public responsibilities shall generally be exercised, in preference, by those authorities which are closest to the citizen. Allocation of responsibility to another authority should weigh up the extent and nature of the task and requirements of efficiency and economy.' [point 3 of Art. 4 of the Charter]

15 However, the status of Margitsziget [Margaret Island] was changed in 2013 by an act. The Fundamental Law prescribes that the capital is divided into districts, but under the Local Governments Act it has one more part, the Margitsziget. The Constitutional Court has not examined this inconsistency substantially. [Order 3105/2014. (IV. 17.) AB]

16 'Helyi és regionális demokrácia Magyarországon' (Local and regional democracy in Hungary) Új Magyar Közigazgatás 2014/1. 6. 
levels, etc. ${ }^{17}$ The Venice Commission also deplored the lack of protection of fundamental rights. ${ }^{18}$ However, I must say that the new regulation does not expressly violate the rules of the Charter.

\subsection{Changes in Functions and Responsibilities of Local Self-Governments}

Beyond the competences determined in the Fundamental Law, the tasks of local governments are prescribed in Acts. First of all, the Local Governments Act contains a list of tasks, ${ }^{19}$ which is not exhaustive; namely, an Act may provide for other municipal tasks additional to those specified therein. [Art. 13 of the Local Governments Act]

On the other hand, this list is only 'a menu', as the specific rules regarding the tasks are determined in specific Acts (e.g. which local government perform them under which conditions). Consequently, not all of them may be considered as compulsory tasks for all kinds of local governments, but there are chosen tasks among them as well. In the determination of competences, an important factor is the differentiation, which also remained within the scope of specific laws.

Many expectations can be fixed regarding the allocation of differentiated competences, such as foreseeability, stability, expertise, proximity to the public, eligibility for funding, capacity to provide the service, compliance with laws, equal opportunities. Nowadays, the Local Governments Act generally sets out, that 'communities, cities, cities with district seat, cities with county rights, the capital and its districts, and the counties may have different functions and responsibilities'. [Art. 11(1) of the Local Governments Act] Competences are differentiated upon the nature of functions and responsibilities, and the diverse conditions of local governments (economic performance, population, size of the administrative territory, etc.). [Art. 11(2) of the Local Governments Act] 'An Act may provide that mandatory tasks of local governments shall be performed through associations' (e.g. joint municipal offices). [Art. 34(2) of the Fundamental Law, Art. 85 of the Local Governments Act]

However, the allocation of tasks shall not be examined only in relation between certain local self-governments, but regarding the state and municipal sphere, as well. Regarding self-governance, it is of major importance. During the preparation of the Local Governments Act the aim was at the determination of municipal tasks that local governments shall perform the general tasks to be performed at local level, and special tasks (e.g. special expertise, specialized care, tasks with larger catchment area, etc.) shall remain to the State.

It is commonly agreed that the responsibilities of local governments are and have been changing from time to time. This hasn't changed since the entry into force of the new Local Governments Act. I review the main lines in the next chart:

17 'Helyi és regionális demokrácia Magyarországon' (Local and regional democracy in Hungary) 2014, 13.

18 'Helyi és regionális demokrácia Magyarországon' (Local and regional democracy in Hungary) 2014, 9. Opinion no. 621/2011 on the new Constitution of Hungary. Adopted by the Venice Commission at its 87th Plenary Session (Venice, 17-18 June 2011) <http://www.venice.coe.int/ webforms/documents/?pdf=CDL-AD(2011)016-e>.

19 Art. 13 of the Local Governments Act. 


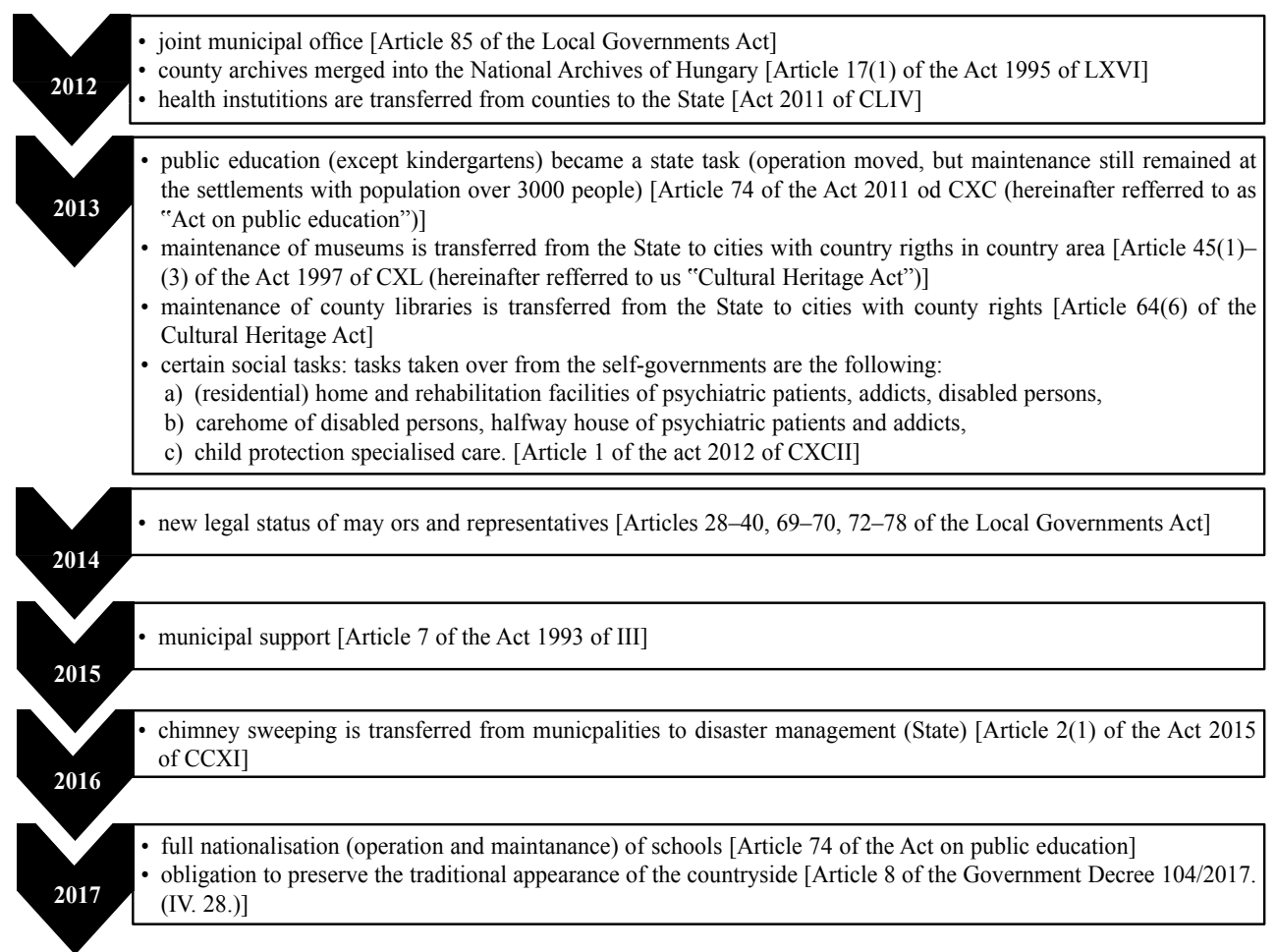

\section{Chart 1. Main changes in municipal tasks (2012-2017) (Source: author's design)}

In accordance with the subsidiarity principle, which is declared neither in the Fundamental Law, nor in an Act, public responsibilities shall generally be exercised, in preference, by those authorities which are closest to the citizen, and tasks shall be assigned on other local self-governments or organs only in the case, if it exceeds the administrative area of the settlements upon its nature or significantly violates the effectiveness requirements and is justified also upon professional point of view. ${ }^{20}$ The Monitoring Committee of the Council of Europe has the same position thereon: the reform and rationalisation of local government system based only on financial aspects is not in compliance with the principle of local selfgovernance, as it runs counter to the provisions of the Charter, which is the following: 'local self-government denotes the right and the ability of local authorities, within the limits of the law, to regulate and manage a substantial share of public affairs under their own responsibility and in the interests of the local population. ${ }^{21}$ [point 1 of Art. 3 of the Charter] The Hungarian reform of municipal tasks is based on the concepts that on the one hand, the general tasks shall remain with the local self-governments and the specific tasks shall be transferred to the State, and on the other hand, every Hungarian citizen shall get equivalent public service, regardless of where he/she lives.

20 Verebélyi (1995b) 549.

21 'Helyi és regionális demokrácia Magyarországon' (Local and regional democracy in Hungary) (2014) 13. 
It is obvious that the public service under certain population cannot be provided in an effective way. But it is not so simple. ${ }^{22}$ For instance, the position of persons living next to the border, the geographical conditions, tourism features, urban and industrial areas, etc. are very diverse. The effectiveness of service is determined by social embeddedness and its open (partnership) or closed (public power) nature. The concept is erroneous and simplistic, being based only ${ }^{23}$ on the number of inhabitants. The fact is that in Hungary there is a village where only 9 persons live (Iborfia, Zala County, 2015), but the types of settlements ${ }^{24}$ and counties show a different picture anyway. ${ }^{25}$ Thus thinking must be more differentiated and complex regarding the determination of municipal tasks, than the legislator drawing a line concerning the number of inhabitants, even though the latter is an objective factor. The Local Governments Act differentiates on the basis of types of local self-government, the nature of functions and responsibilities, the different situations of local governments (e.g. especially economic performance, population, the size of the administrative territory, etc.). [Art. 11 of the Local Governments Act]

This can be considered as the biggest deficiency of the Local Governments Act. While the number of municipal tasks has significantly decreased, the structure of small village municipalities has remained unaffected. However, the formal autonomy does not come with real power.

Several studies have dealt with how the public services that are provided at a proper level have an effect on adjacent area as well. From these advantages not only the people living in the territory of the municipality benefit. Effective and proper task performance has spillover effect. First, because in many cases not only the people living in the settlement use the public service. Second, because voters may force municipality to provide the appropriate care (e.g. by moving away, unless their needs are met in the settlement). ${ }^{26}$ At this point, I must mention that the public choice theory is more complex, as the spatial mobility of citizens is influenced by several factors, not only the level of services. It is very difficult to handle it in an Act.

We must find international examples of the allocation of tasks, but there is no rule that would provide for implementing the so-called municipal model with wide responsibilities in Hungary. I must refer to the fact that it is not the length of the task list that determines the 'quality' of the democracy: wide responsibilities may not prevent corruption, partiality, etc., and also the authority with limited tasks may be professional, customer-focused, etc. ${ }^{27}$

It is beyond dispute that without questioning the raison d'etre of the local and regional deconcentrated and decentralized organs, the consistency in the public administration needs to be organized upon clear concept supported by rational reasons, and not how the uncertainties, fairness, etc. of respective ministerial interests would determine the organisational structure. ${ }^{28}$

22 Zongor (2014) 84.

${ }^{23}$ E.g. in case of formation of joint municipal office. [Art. 85 of the Local Governments Act]

$2453 \%$ of the Hungarian settlements is of population under 1000 people, $32 \%$ is of population under 500 inhabitants. Thus, the settlement pattern in Hungary is of small villages. [Hóbor and Varga (2009) 110.]

25 Zongor 2014, 85.

26 De Siano and D’Uva (2017) 1508.

27 Horváth M. (2012) 8.

28 Ivancsics (1994) 171. 


\subsection{Change in Financial Autonomy of Local Self-Governments}

The Constitutional Court examined the funding of local self-governments also in the era of the Constitution. It stated that point c) of Art. 44/A of the Constitution places an obligation to the State: the legislator shall provide funds necessary for the compulsory municipal tasks by determining their own revenue sources and state support commensurate to the scope of such duties. Upon this provision, the Parliament freely decides on the resources of the duties set out in Acts. The resources necessary for the duties to be compulsory performed by local governments are ensured by the complex system of their own revenue and of the central budget contribution by the Parliament. [Decision 2/1997. (I. 22.) AB, ABH 1997, 27, 31.] It is the political responsibility of the Parliament and is not a constitutional issue, whether the funding of local self-governments is appropriate. It would be a constitutional issue, if it violated a provision of the Constitution [now: Fundamental Law - the Author], or led to deprivation from autonomy (e.g. no fund would be provided, operation would become impossible). [Decision 48/2001. (XI. 22.) AB, ABH 2001, 336.]

The same applies to the entry into force of the Fundamental Law, as local governments continue to exercise the rights of ownership with respect to local government property, determine their budgets and autonomously manage their affairs on the basis thereof, engage in entrepreneurial activities with their assets and revenues available for this purpose, without jeopardising the performance of their mandatory duties and decide on the types and rates of local taxes. [points e)-h) of Art. 32 of the Fundamental Law] Consequently, the Parliament has and had more discretion regarding the funding and economical system of local self-governments, included but not limited to the determination of the ownership for providing local public services. ${ }^{29}$

However, there are several new statutory restrictions concerning the municipal management which are based on Art. 34(5) of the Fundamental Law. This states the following: 'In order to preserve a balanced budget, an Act may provide that for any borrowing or for other undertaking of commitments by local governments to the extent determined in an Act, certain conditions and/or the consent of the Government shall be required.'

If statutory conditions are met, local self-governments may ensure guarantee under the Civil Code or contract a loan with the consent of the Government. [Art. 10(1) of the Act 2011 of CXCIV]. This model has the strictest borrowing limit, which has the advantage that the Government can influence the municipal debts which is a part of state debt, at the same time this has the risk to exercise it abusively. ${ }^{30}$ In my opinion, the restriction regarding the undertaking of municipal commitment is formally consistent with the provisions of the Charter, according to which 'local authorities shall be entitled, within national economic policy, to adequate financial resources of their own, of which they may dispose freely within the framework of their powers'. [point 1 of Art. 9 of the Charter]

The consent of the Government is necessary not only for borrowing, but for investments provided by EU or international organization, as well, 'if the deadline of the commitments undertaken towards the European Union or other international organization

29 The Constitutional Court shall examine only the constitutionality of restrictions, but not the effectiveness of organization of public tasks. [Decision 3180/2018. (VI. 8.) AB, ABH 2018, 867, 871-72.]

30 Kecső (2013) 11. 
has elapsed without result, or there is a real danger of non-execution within deadline, the Government may execute the investment related to the commitment at its own discretion. The Government shall decide in an individual decision about the execution of the investment at its own discretion.' [Art. 16(1) of the Local Governments Act]

In case of such investment, it has a particular interest in its execution, as in many cases it has happened that the local self-government contracted with financing body has had a significant slippage regarding the investment, jeopardizing the performance of the EU commitment. In this case, paying back the support and also paying penalties are to be expected. ${ }^{31}$ But the Government's decision may be challenged before the court. [Art. 16(2) of the Local Governments Act]

It is also important to say that it may happen in the case determined in the Budget Act that local governments shall pay solidarity contribution to the State. More precisely, this contribution is withdrawn from the monthly amount of the support to be paid for local governments. [Art. 40(4) and Chapter V of Annex 2 of the Act 2018 of L] In my opinion, this regulation does not necessarily encourage local self-governments to earn revenue.

\subsection{Changes in Control over Local Self-Governments}

In compliance with the Charter, the Fundamental Law leaves the legal supervision of local self-governments to the executive power. By entering the new Local Governments Act into force (from 1 January 2012), offices of the capital/county government perform the legal supervision instead of legal control. ${ }^{32}$ Supervision means an additional power (control plus measures). I must highlight that it is not the name that matters, but the scope and method of the review mechanism. It gives assurance that the supervision shall only take place from a legal perspective, and the final decision is made by the court and not by the Government. [Art. 15(2), 18(2) and 34(4) of the Fundamental Law]

What review mechanisms have in common is that they are related to ex-post control; however, we know special preliminary monitoring mechanisms, as well (e.g. the consent of the Government for borrowing). Beside review mechanism, offices of the capital/county government provide opportunity to local governments for professional consultation. Review mechanisms shall be of secondary importance, as neither of the parties has interest in generating legal disputes.

I deal with the review mechanisms within this study that have been changed in the near past and concern the issue of the autonomy of local governments.

A kind of review mechanism is the competence of the substitution of a municipal decree. In this case, the court can decide on the establishment of non-compliance of a local government with its obligation based on an Act to legislate. In case of non-compliance with municipal legislative obligation, the process splits into two parts. Firstly, the Curia shall establish whether the local government is in compliance with its municipal legislative obligation and if not, shall oblige the local government to adopt the municipal decree. ${ }^{33}$ So the Local Governments Act gives the local governments the possibility to eliminate failure. If the body of representatives fulfils the legislative obligation, the Curia shall close the proceedings. ${ }^{34}$ 'If the local self-government does not fulfil its legislative obligation

31 Simon and Tóth (2015) 72.

32 Art. 34(4) of the Fundamental Law.

33 Tilk (2012) 5 .

34 Tilk (2012) 8 . 
within the deadline determined by the Curia, the offices of the capital/county government shall initiate the Curia within 30 days after the expiry date to order the fulfilment of the obligation by the offices of the capital/county government.' [Art. 137(3) of the Local Governments Act] This will be the second stage of the proceedings. As a guarantee rule, this authorization of the head of the office of the capital/county government is not an automatic element, it attaches to an initiation of the proceedings. However, the local selfgovernment is no longer allowed to adopt the municipal decree after this decision of the Curia.

In this stage, the Curia entitles and at the same time oblige the head of the office of the capital/county government to adopt the municipal decree. ${ }^{35}$ Regarding the legal outcome of the municipal decree adopted by the head of the office of the capital/county government two circumstances worth underlining: also this decree shall be considered as a municipal decree, but 'the local government is entitled to amend or repeal it only after the next municipal election, during this time the head of the office of the capital/county government is entitled to do so'. [Art. 138(3) of the Local Governments Act] This provision generated a dispute among professionals. If the Act did not contain any restrictions regarding the 'retention' of the municipal decree adopted by the head of the office of the capital/county government, the substitution would not achieve its purpose.

The problem is especially pronounced when the amendment or the repeal become necessary later (e.g. because of the development of legislation). In this case, the legal outcome of the decree depends on the office's goodwill and cooperation. It is questionable whether it is an acceptable alternative solution to adopt another municipal decree by the body of representatives in the same scope, but with different content. In this case, the law will not be breached formally, but in content it will, because it would not amend the municipal decree substituted. ${ }^{36}$

In the beginning, many people were afraid of how the head of the office of the capital/ county government will prepare for the adoption of a sufficiently differentiated municipal decree, as it cannot know the local situation, has no information about the subject matter of the legislation and has no experience in legislation. It was warned against patterns and templates. There was a fear that local governments pass on the unpleasant decision to the head of the office of the capital/county government (e.g. designated zones for prostitutes, Art. 8(1) of the Act 1999 of LXXV). ${ }^{37}$ The question arises as to whether the head of the office of the capital/county government draw the line of the strictly necessary rules in a correct way? What is the situation, if it goes beyond its competence and if it concerns political issues as well?

Another important question regarding the municipal decree adopted by the head of the office of the capital/county government: who will practice the control above its municipal decree? It is obvious that nobody will initiate review proceedings against themselves. However, a legal norm cannot remain without constitutional or legal control. The solution can be that the Government, as the general organ of executive power, may supervise the municipal decree under Art. 15(1) of the Fundamental Law. ${ }^{38}$

Regulatory autonomy belongs to the immanent part of self-governance; however, there are many restrictions with guarantees in the Act. It is observed that proceedings are

\footnotetext{
35 Tilk (2012) 5.

36 Tilk (2012) 6.

37 Tilk (2011) 13.

38 Demeter (2012) 16.
} 
protracted and the substituted municipal decree cannot actually reach its purpose (pl. budget decree is promulgated after the budget year). Perhaps it is more effective in that regard if the local government does not adopt its budget for the budget year or the final accounts for the previous year, or does not fulfil the reporting obligation on public finance or the property registration, certain allowances therefore shall be suspended under the Act on Public Finance. [Art. 111/A of the Local Governments Act]

Moreover, in case of substitution of a decision, which is the final competence of the administrative and labour court, similar questions arise to case of the substitution of a municipal decree: who will challenge the unlawful decision of the head of the office of the capital/county government? There are no restrictions for immutability regarding the substituted decision. In many cases it could lead to extreme situations, in what kind of scope the office of the capital/county government is entitled to act (e.g. appointment of deputy mayor). ${ }^{39}$

In case of non-compliance of a local government with its obligation to perform tasks, it is worth examining why the local government does not perform its compulsory municipal task. It may stem from financial reasons. May the legal review mechanism be effective in this case $?^{40}$

In light of the above, it is also an interesting question, whether the concept of the legislator was that the administrative and labour court as the representative of the judicial power shall substitute the decision and the obligation to perform municipal tasks, why the waste management public service is referred to the competence of disaster control service? [Art. 1(1) of the Act 2013 of CXXXIV]

From 1 January 2012 the scope of constitutional control was narrowed down. If the office of the capital/county government finds the municipal decree unconstitutional, it may have recourse through the Government to the Constitutional Court upon its motion submitted at the minister responsible for the legal supervision of local governments. [Art. 136(1) of the Local Governments Act] A further limit is that the office may act this way only after the notice for legality was issued or the body of representative was convened. After having examined this motion, the minister, if the conditions are satisfied, initiates at the Government to propose the municipal decree's examination of the compliance with the Fundamental Law.

Because of the limited ex-post norm control proceedings, the constitutional complaint can be the tool to examine unconstitutional municipal decree. Its disadvantage is that the examination of the Constitutional Court may be delayed, and the Constitutional Court rarely decide on retroactive application, thus it does not necessarily lead to real legal redress.

It can be argued that both the Curia and the Constitutional Court have competence for examination of municipal decree. If the municipal decree violates both the Fundamental Law and also other laws, it is not justified to open two proceedings: because of the limitation period of 15 days, the office of the capital/county government will recourse to the Curia. ${ }^{41}$

Neither the legal supervision fine will become a motivational tool at the office of the capital/county government. The notice for legality shall precede the legal supervision fine which shall be performed within 30 days by the addressee. So, for instance if the notary

39 Demeter (2012) 17.

40 Lörincsik (2013) 133.

41 Demeter (2012) 15. 
does not used to transfer the minutes of the board meeting, this measure cannot be effective for the enforcement of the lawful conduct. ${ }^{42}$

The office of the capital/county government may impose legal supervision fine of between HUF 38,650 and 386,500 in the cases listed in Art. 141(1) of the Local Governments Act which are deliberate, but different serious infringements. ${ }^{43}$ Non-execution of a request cannot be compared to non-execution of a public service which was observed by the legislator, too, thus the seriousness of the infringement, the fiscal position of the local self-government and the number and amount of the previous fine shall be taken into consideration at determining the amount of the fine. ${ }^{44}$

On the whole, regarding legal supervision, the overall picture is very mixed, there are several innovations and interesting solutions beside restricting provisions. ${ }^{45}$ The legislator tries to maintain consistency with the Charter regarding the legal supervision. It can be stated that the offices of the capital/county government are strengthened in the Local Governments Act, but many review mechanisms cannot be reasonably carried out. Another important remark is that the supervisory procedure may turn to court proceedings in almost every case, namely the judicial control appears alongside the control of the office of the capital/county government. From this perspective, from among the competences only the notice for legality and the right to initiate proceedings remained effectively and finally at the office of the capital/county government. The key to lawful operation is in cooperation: in this case the balance between the municipal autonomy and the state sovereignty can be maintained. ${ }^{46}$

\section{CONCLUSIONS}

In my opinion, the relationship between the municipal system and the State has been redefined. The purpose is 'to establish the municipal system more integrated in the state organizational system, in which the instruments influencing local self-governments of the central state organs are strong and of an operational nature'. ${ }^{47}$ As the preamble of the Local Governments Act states: local self-governments are obliged to contribute to achieve state goals and to perform legal obligations. ${ }^{48}$ The scope of rights for local governments and the levels of local self-governments were not actually changed. Moreover, regarding the content of self-governance I can say that the Government 'may influence'49 local self-governments strictly limited to the framework of an Act. Municipal duties, the scope of rights and the external interference determine the degree of autonomy.

The Hungarian regulation is literally and formally in compliance with the provisions of the Charter, but examining the spirit of the Charter the opposite conclusion is reached. Contracting parties agreed that they strengthen the existing municipal system and they endow it with essential functions. The current trends are precisely the opposite, but I cannot

42 Demeter (2012) 17.

43 Lörincsik (2013) 133.

44 Lörincsik (2013) 134.

45 Balázs (2012a) 40.

46 Lörincsik (2013) 135.

47 Balázs (2014) 36.

48 Balázs (2012b) 216.

49 Ó Erlingsson and Ödalen (2013) 37. 
say that local governments have become weightless. ${ }^{50}$ Regression can be experienced for effectiveness regarding the former existed level of autonomy ${ }^{51}$, it is especially so in the light of the changes in the Fundamental Law, in the municipal tasks and in the situation of the financing system. However, the question is what kind of changes are expected. I think we cannot now speak about a change in paradigm, because the new rules do not place local self-governments on a totally new basis, but we can speak about a paradigm crisis.

As a result, the relation between the State and the municipal system is a complex issue. ${ }^{52}$ The municipal system cannot be examined on its own, but in relation with the administrative reform of the State. Municipal autonomy means, on the one hand, that local self-governments have freedom in many fields, and on the other hand, that they cooperate and improve their cooperation with the State, regarding the state influence to the municipal system. The aim would not be to emphasize weights and balances, but the long-term strategic cooperation, as there are many contact points regarding their duties. The degree of autonomy can be an issue, but it is over dispute that the success of state and municipal organs also depends on how they can cooperate with each other. I believe that the municipal model implemented by the regime change moves towards integration model, according to which state sovereignty is single and indivisible. Consequently, local self-governments have only transferred duties. The role of municipalities is that they can organize tasks in an easier, more flexible and more practical way (e.g. community cooperation), thus increasing the interaction between different organizations and the civil field. ${ }^{53}$ Furthermore, it must be seen, too, that local self-governments form not only a localised, but also a globalised system, to which settlements shall react.

\section{LITERATURE}

Balázs, I., 'A helyi önkormányzati autonómiafelfogás változása az új törvényi szabályozásban' (Changes in the conception of the municipal autonomy in the new statutory regulation) (2012a) 10 Új Magyar Közigazgatás 37-41.

Balázs, I., 'Az autonómia-felfogás változása az új magyar helyi önkormányzati szabályozásban' (Changes in the conception of the autonomy in the new Hungarian regulation on local selfgovernments) (2012b) 2-3 Állam- és Jogtudomány 213-41.

Balázs, I., 'Az önkormányzatokra vonatkozó szabályozás átalakulása' (Changes in the regulation regarding local self-governments) (2014) 1 Új Magyar Közigazgatás 35-40.

Demeter, A., 'Prognózis a törvényességi felügyelet várható gyakorlatáról' (Prognosis on expectable practice of legal supervision) (2012) 7-8 Új Magyar Közigazgatás 11-19.

De Siano, R. and D’Uva, M., 'Fiscal decentralization and spillover effects of local government public spending: the case of Italy' (2017) 10 Regional Studies 1507-17.

'Helyi és regionális demokrácia Magyarországon' (Local and regional democracy in Hungary) (2014) 1 Új Magyar Közigazgatás 6-23.

Hóbor, E. and Varga, T., 'A helyi önkormányzati rendszer müködésének gyakorlati tapasztalatai az aprófalvakban. Javaslat a jogszabályi reformra' (Practical experiences of the operation in local self-government system. Proposal for legislative reform) in F Sükösd (ed), Emlékkönyv Markos György egyetemi adjunktus tiszteletére (Kódex Nyomda 2009) 109-19.

50 Balázs (2012a) 41.

${ }^{51}$ It is also an interesting question whether there are degrees of autonomy. If we define autonomy as actions with inner commitment and without external duress [Varga (2004) 71.], it is hardly conceivable that inner commitment and external duress can coexist.

52 Kaltenbach (2010) 43.

53 Horváth M. (2002) 87. 
Hoffman, I., 'Az önkormányzati feladat- és hatáskörök átalakított rendszere az önkormányzati törvényben' (Modified structure of the functions and responsibilities of local governments in the Local Governments Act) (2013) 7-8 Új Magyar Közigazgatás 10-18.

Horváth M., T., Helyi közszolgáltatások szervezése (Organisation of local public services) (Dialóg Campus 2002).

Horváth M., T., 'Kiszervezés - visszaszervezés. A helyi közszektor változása' (Outsourcing insourcing. Changes of local public sector) (2012) 2 Fundamentum 5-10.

Ivancsics, I., 'A hatáskörmegosztás elméleti és gyakorlati problémái' (Theoretical and practical problems of the division of power) (1994) 3 Magyar Közigazgatás 169-72.

Kaltenbach, J., 'Néhány gondolat az önkormányzatok és a központi hatalom viszonyáról' (Some thoughts about the relation of local governments and central power) in L Kákai (ed), 20 évesek az önkormányzatok. Születésnap vagy halotti tor? (Molnár Nyomda 2010) 43-49.

Kecső, G., 'A helyi önkormányzatok gazdálkodásának egyes kérdései nemzetközi kitekintésben' (Certain issues of the management of local self-governments with international outlook) (2013) 1 Új Magyar Közigazgatás 8-15.

Kuhn, T., The Structure of Scientific Revolutions (Chicago UP 1970).

Küpper, H., 'A helyi önkormányzás joga' (Right of local governance) in A Jakab (ed), Az Alkotmány kommentárja II. (Századvég 2009) 1500-24.

Lőrincsik, P., 'A helyi önkormányzatok feletti törvényességi kontroll új szabályai' (New rules of statutory control over local self-governments) in Zs Fejes, E Kovács, M Endre, P Paczolay and JZ Tóth (eds), Állam és jog - Kodifikációs kihivások napjainkban (Gondolat 2013) 127-35.

Murányi, P., 'From transition to transfusion: the rise and fall of local governments in Hungary' (2015) 298 Summer Regions 10-12.

Ó Erlingsson, G. and Ödalen, J., 'How Should Local Government Be Organised? Reflections from a Swedish Perspective' (2013) 1 Local Government Studies 22-46.

Opinion no. 621/2011 on the new Constitution of Hungary. Adopted by the Venice Commission at its 87th Plenary Session (Venice, 17-18 June 2011) <http://www.venice.coe.int/webforms/ documents/?pdf=CDL-AD(2011)016-e > accessed 1 July 2019.

Pálné Kovács, I., 'Helyi önkormányzatok és végrehajtó hatalom' (Local governments and executive power) in F Glatz (ed), A demokrácia intézményrendszere Magyarországon (Budapest: MTA 1997) 115-30.

Simon, B. and Tóth, F., A közszolgáltatások szervezése a változó gazdaságban (Organisation of public services in changing economies) (Nemzeti Közszolgálati Egyetem 2015).

Szente, Z., 'A helyi-területi önkormányzatok alkotmányos szabályozásának elvei de lege ferenda' (Principles of the constitutional regulation of local-regional self-governments with a view to the future law) (1994) 6-7 Magyar Közigazgatás 364-87.

Tilk, P., 'Gondolatok a kormányhivatalok vezetőinek önkormányzati rendeletalkotásra vonatkozó (pótlási) hatásköréröl' (Thoughts about the competence regarding the municipal legislation of the head of the office of the capital/county government) (2011) 8 Új Magyar Közigazgatás 8-15.

Tilk, P., ‘Az önkormányzati jogalkotás törvényességi és alkotmányossági kontrollja' (Legal and constitutional control of municipal legislation) (2012) 7-8 Új Magyar Közigazgatás 3-10.

Ujlaki, A., 'Az állam és az önkormányzat alapjogi jogalanyisága' (The State's and local selfgovernments' legal entity of the nature of fundamental rights) (2018) 3 Jogelméleti Szemle 97107.

Varga, Cs., A jogi gondolkodás paradigmái (Paradigms of legal thinking) (Szent István Társulat 2004).

Verebélyi, I., 'Az önkormányzatiság alkotmányos alapjai' (Constitutional basis of self-governance) (1995a) 9 Magyar Közigazgatás 481-92.

Verebélyi, I., 'Az önkormányzatiság alkotmányos alapjai (II.)' (Constitutional basis of self-governance II.) (1995b) 10 Magyar Közigazgatás 545-61.

Zongor, G., 'Önkormányzati vissza- és elöretekintés, avagy szubjektív értékelés az elmúlt csaknem negyedszázadból' (Municipal retrospect and foresight, or a subjective assessment from the almost past quarter century) (2014) 1 Új Magyar Közigazgatás 83-87. 


\section{LEGAL MATERIAL}

Fundamental Law of Hungary

Act XX of 1949 on the Constitution of the Republic of Hungary

Act III of 1993 on social administration and social care

Act LXVI of 1995 on public records, public archives and the protection of private archival materials

Act XV of 1997 on promulgation of the Convention on the European Charter of Local Selfgovernment done in Strasbourg on 15 October 1985

Act CXL of 1997 on museum institutions, public library services and public culture

Act LXXV of 1999 on the rules of actions against organised crime and certain phenomena related thereto and on amendments of laws related thereto

Act CLIV of 2011 on consolidation of regional self-governments and on the takeover of the institutions of regional self-governments and certain health institutions of the capital selfgovernment

Act CLXXXIX of 2011 on Local Governments in Hungary

Act CXC of 2011 on national public education

Act CXCIV of 2011 on economic stability of Hungary

Act CXCII of 2012 on the state takeover of certain special social and child protection institutions and amendments of certain Acts

Act CXXXIV of 2013 on providing certain public service and amendments of laws related thereto

Act CCXI of 2015 on the activity of chimney sweeping

Act L of 2018 on the 2019 central budget of Hungary

Government Decree 104/2017. (IV. 28.) on the implementation of the provisions related to advertising of the Act on preservation of the traditional appearance of the countryside

Decision 1/1993. (I. 13.) AB

Decision 55/1994. (XI. 10.) AB

Decision 2/1997. (I. 22.) AB

Decision 48/2001. (XI. 22.) AB

Decision 18/2013. (VII. 3.) AB

Decision 3180/2018. (VI. 8.) AB

Order 3105/2014. (IV. 17.) AB

\section{OPEN ACCESS}

This is an open-access article distributed under the terms of the Creative Commons Attribution 4.0 International License (https://creativecommons.org/licenses/by/4.0), which permits unrestricted use, distribution, and reproduction in any medium, provided the original author and source are credited, a link to the CC License is provided, and changes - if any - are indicated. (SID_1). 